\title{
VIRTUAL ESCAPE ROOM AND STEM CONTENT: EFFECTS ON THE AFFECTIVE DOMAIN ON TEACHER TRAINEES
}

\author{
Félix Yllana Prieto (iD, Jin Su Jeong (iD), David González-Gómez (iD \\ Departamento de Didáctica de las Ciencias Experimentales y \\ Matemáticas, Universidad de Extremadura (Spain) \\ feyllanap@unex.es,jin@unex.es,dggomez@unex.es
}

Received November 2020

Accepted March 2021

\section{Abstract}

In recent times, there has been growing disinterest by students in STEM disciplines (science, technology, engineering, and mathematics). This trend is especially acute in those students who do not take STEM content during their secondary or high school education. This disinterest might be conditioned by negative emotions towards science developed by students during the different educational stages, even from an early age. In this sense, active teaching methodologies, such as gamification, play a fundamental role in fostering positive emotions towards learning STEM content. Within the wide range of gamification methodologies, we find educational Escape Rooms. Due to the current situation generated by COVID-19, many of the lessons have had to be adapted to a virtual format through various online platforms. In this study, in a preliminary manner, we aim to analyze the effects on the affective domain produced by a virtual Escape Room used in a STEM course as an instructional tool to teach contents about the Universe to teachers in training. According to the results obtained, the positive emotions of "happiness", "satisfaction" and "fun" are significantly increased after the intervention. At the same time, some negative emotions, such as "nervousness", "frustration" and "worry" also increase, partly due to the components typically found in this type of games. Based on these results, it is concluded that, despite the existence of both positive and negative emotions, the results are promising and the intervention is motivating and stimulating for the students.

Keywords - Virtual Escape Room, Gamification, Emotions, STEM, Flipped-Classroom.

\section{To cite this article:}

Yllana-Prieto, F., Jeong, J.S., \& González-Gómez, D. (2021). Virtual escape room and STEM content: Effects on the affective domain on teacher trainees. Journal of Technology and Science Education, 11(2), 331-342. https://doi.org/10.3926/jotse.1163

\section{Introduction}

Today, there is great interest in providing good training for students in subjects and degrees related to science, technology, engineering, and mathematics (STEM), due to concerns about the decline of interest in some STEM fields by students in recent years (Miller, Sonnert \& Sadler, 2018; Sánchez-Martín, Corrales-Serrano, Luque-Sendra \& Zamora-Polo, 2020). The term STEM was first coined by the National Science Foundation (NSF) in 1990 as an acronym for Science, Technology, Engineering and Mathematics, but the concept did not become well-known until 2003 (McComas, 2014). STEM education proposes the 
integration of various scientific disciplines as a cohesive entity, the teaching of which is integrated and coordinated, as used in problem solving in everyday situations (Sanders, 2009). In this sense, the importance of promoting the integrated learning of mathematics and sciences without the barriers that separate the two disciplines is emphasized (Ferrando, Hurtado \& Beltrán, 2018). Faced with this challenge, it is important to take into account student preferences and to generate interests in scientific disciplines from an early age, as these preferences and interests persist into adulthood and may impede or facilitate the choice of STEM careers (Tai, Liu, Maltese \& Fan, 2006). For example, Wiswall, Stiefel, Schwartz and Boccardo (2014) suggest that students who participate in STEM-focused programs and activities earn higher grades on math and science tests than those who do not participate. Furthermore, it is observed that students who participate in these STEM programs choose STEM degrees more often than those who do not participate.

Although the implementation of STEM methodologies can be useful to promote scientific literacy in students, one of the main causes of disinterest in these disciplines is due to the generation of negative emotions towards science by the students (Osborne \& Dillon, 2008). Some studies (Vázquez \& Manassero, 2011; van Aalderen-Smeets \& van der Molen, 2015) have shown that students begin to show disinterest in STEM disciplines at an early age, causing them to have a negative image of science in general, and to abandon their choice of STEM careers later on. In this context, the affective domain in science teaching-learning plays a fundamental role, because the emotional factor is closely connected to the cognitive factor, i.e., encouraging the presence of positive emotions in students during the study of a subject promotes learning, while the generation of negative emotions limits it (Vázquez \& Manassero, 2007). Specifically, this affective domain takes on special importance for teachers in training, where generating positive emotions is useful for them to feel competent and trained for science instruction, since it depends on them to generate interest in science in future generations (Jeong, González-Gómez \& Cañada-Cañada, 2019a).

According to Tobin (2010), traditionally, the teaching of STEM-related subjects has focused on theoretical contents which, combined with the higher difficulty of knowledge, have led to negative emotions by students towards science in general. Prince (2004) indicates that active methodologies, i.e., instructional methods that involve the students in the learning process, can promote academic performance, critical thinking and positive emotions by the students, especially towards science. In addition, other studies have found that the incorporation of active methodologies increases positive emotions towards science teaching and learning (Méndez, 2015; González-Gómez, Jeong \& Cañada-Cañada, 2019). One instructional methodology that focuses on the learner and makes them the priority is the flipped classroom methodology. This methodology consists of providing video lessons together with written material and online assessments for students to work on the theoretical contents asynchronously at home and, as a result, student-centered activities, this is practical and cooperative interactive tasks, are carried out during class time. In addition, some of this time can be used to address specific student questions and doubts. (Hill, Song \& West, 2009; Mohamed \& Lamina, 2018; Munir, Baroutian, Young \& Carter, 2018). This type of methodologies has become especially important during the COVID-19 pandemic because, for health and safety reasons, it is necessary for teachers to explore ways of teaching based on digital media (Chick, Clifton, Peace, Propper, Hale, Alseidi et al., 2020). Numerous studies (González-Gómez, Jeong, Cañada-Cañada \& Gallego-Picó, 2017; Jeong, González-Gómez \& Yllana-Prieto, 2020) reveal that the use of flipped-classroom methodology on STEM contents with teacher trainees is highly beneficial, as it boosts motivation and leads to a significant improvement in the students' academic performance, not only in terms of grades, but also in the rate with which they pass the subjects.

In the context of active methodologies, the use of games in the classroom can increase student satisfaction, grades, cooperation and motivation to learn. In addition, the creation of these educational games provides the opportunity for an interdisciplinary approach, bearing in mind how to promote a realistic environment with the objective of achieving a better experience for the student (Klisch, Miller, Wang \& Epstein, 2012; Vázquez \& Manassero, 2017). Gamification is the use of elements and techniques associated with games in different contexts, for example, in business or education (Deterding, Dixon, 
Khaled \& Nacke, 2011). Several studies have shown successful practices using gamification in university teaching, and even reveal that the students who participate tend to achieve better academic performance and motivation (González, 2014; Su, 2019). Within gamification, Escape Rooms are live action games where players discover clues, solve puzzles and perform tasks in one or more rooms in order to reach a specific goal in a limited amount of time, which will allow them to leave the room (Nicholson, 2015; Borrego, Fernández, Blanes \& Robles, 2017). There are a great number of studies (Brown, Darby \& Coronel, 2019; Gómez-Urquiza, Gómez-Salgado, Albendín-García, Correa-Rodríguez, González-Jiménez \& Cañadas-De la Fuente, 2019; Pérez-Vázquez, Gilabert-Cerdá \& Lledó-Carreres, 2019) on the application of Escape Rooms as an instructional tool in university teaching. These studies point out that during the course of an Escape Room activity, different types of positive emotions are promoted. They highlight the motivation, interest and fun that students experience when tackling the proposed enigmas, as well as their usefulness in promoting cooperative team work in an immersive environment. However, some studies (Clauson, Hahn, Frame, Hagan, Bynum, Thompson et al., 2019; Sierra \& Fernández-Sánchez, 2019) reveal that these types of activities also generate emotions such as stress and frustration, due to factors such as time and competitiveness, especially on items or tests of greater difficulty. Thus, one should try to find the balance between difficulty and time, so that participants do not get bored, but also do not get frustrated. Worth noting is the importance of connecting teaching-learning activities to the story and context of the escape game, thus engaging students in the narrative, which can inspire students to reflect on how learning is connected to real problems, and help them to develop intrinsic motivation to learn and engage in further exploration, rather than merely seeking extrinsic motivation from grades (Nicholson, 2018; Sánchez-Martín et al., 2020).

Fostering interest in STEM remains a challenge. This research is a preliminary study, and its main objective is to analyze the effects on the affective domain produced by the implementation of a virtual Escape Room used as an instructional tool to teach content about the Universe in a STEM subject to teacher trainees studying for a degree in Primary Education at the University of Extremadura (Spain).

\section{Methodology}

To analyze how student emotions are affected, a comparative study is carried out between the answers on a questionnaire given before and after (pre- and post- test) the proposed intervention.

\subsection{Sample}

The study sample consists of 42 trainee teachers enrolled in the subject "Knowledge of the natural environment in primary education", which is taught using flipped-classroom methodology in the fourth year of the Primary Education degree (University of Extremadura), during the first semester of 2020/2021 academic year. No restrictions were imposed, and the students freely chose whether they wanted to participate in the research. The average age of the 42 students who participated in the study is 23. Table 1 shows the demographic information of the sample in greater detail. It should be noted that students enrolled in the Primary Education degree have mainly studied Humanities or Social Sciences during their pre-university education; in this case, they account for $69.05 \%$ of the participants.

\begin{tabular}{|c|c|c|c|c|c|c|c|c|c|c|}
\hline \multirow[b]{2}{*}{$\begin{array}{c}\text { Sample } \\
\text { size }\end{array}$} & \multicolumn{2}{|c|}{ Gender (\%) } & \multicolumn{3}{|c|}{ Age $(\%)$} & \multicolumn{3}{|c|}{ Specialty $(\%)$} & \multicolumn{2}{|c|}{$\begin{array}{l}\text { Access to the } \\
\text { University through } \\
\text { Baccalaureate }\end{array}$} \\
\hline & Male & Female & $20-25$ & $26-30$ & $>40$ & $\begin{array}{l}\text { Humanities or } \\
\text { Social Sciences }\end{array}$ & Sciences & Other & Yes & No \\
\hline 42 & 45.24 & 54.76 & 90 & 5 & 5 & 69.05 & 26.19 & 4.76 & 88.09 & 11.91 \\
\hline
\end{tabular}

Table 1. Demographic description of the sample 


\subsection{Course Context and Procedure}

The subject is structured into 3 general topics that deal with contents related to the different current challenges in scientific education, the teaching of science in primary education through different strategies and projects, and instructional resources and materials related to the curriculum of Knowledge of the Natural Environment in Primary Education. According to the syllabus, students need a total of 150 hours to complete the course, of which 45 are spent in face-to-face classes, 15 hours on practical activities and 90 hours on remote activities.

The 42 participants belong to the same group that is taking the subject in which the intervention is implemented. To start with, a few days before the activity, students complete a questionnaire about the emotions they felt before the intervention (pre-test). The activity is an online Escape Room about scientific content related to the Universe, and it is carried out as a practical activity in one session. Due to the current COVID-19 situation, both the session and the intervention are carried out virtually, using the Zoom platform. In this way, the teacher trainees complete the Escape Room individually from their respective homes, on their computer, tablet or smartphone. Finally, the last ten minutes of the session are spent filling out a questionnaire that analyzes the emotions that students had after performing the intervention (post-test).

Since this is an activity that is taught using a flipped classroom methodology, prior to the completion of the virtual Escape Room, students must read and review the interactive educational material that the teachers have provided on the virtual campus. This material consists of video lessons in which the teacher explains to the students the theoretical contents related to the Universe, which will be worked on in the virtual Escape Room. In addition, on the virtual campus, before the activity is carried out, students have the possibility to ask any questions or doubts that may have arisen during the viewing of the video lesson provided. It is important to ensure that all the theoretical contents are perfectly assimilated by the students prior to the activity, in order to satisfactorily complete the virtual Escape Room activity.

Teachers encourage the interaction and involvement of students in the case study through the virtual session, playing an active role and providing constant attention to the doubts and solutions generated by the students. In order to motivate and involve students to actively participate in these activities, participation in this activity was assessed taking into account the speed with which students solve the tests and complete the activity when participating in the intervention.

\subsection{Instrument}

The data was collected by means of a questionnaire used to assess the emotions felt by the participants in this study in expectation of completing an Escape Room about the Universe, and those they actually feel during the course of the activity (pre- and post-test). This questionnaire is quantitative and self-reported, i.e., a Likert scale of 1 to 5 points is used and students assess their own emotions. The questionnaire has been validated in other studies (Dunbar, Dingel, Dame, Winchip \& Petzold, 2016; Jeong et al., 2019a).

Students are asked about 10 emotions, 5 positive (happiness, confidence, satisfaction, enthusiasm and fun) and 5 negative (worry, frustration, uncertainty, nervousness and boredom). These feelings are selected from among the emotions that students may experience in a teaching-learning process, according to the classification in groups of positive and negative emotions made by Bisquera (2005). Specifically, these emotions are quantified from 1 to 5 , with a value of 1 corresponding to never having felt that emotion and value 5 to having felt it very intensely. Value 3 is the intermediate value, and values 2 and 4 specify "a little" and "quite a lot", respectively.

\subsection{Escape Room Design}

To cover the contents about the Universe, a virtual Escape Room is conducted in one session, via a videoconference. Specifically, the theoretical content of the intervention is based on the solar system, where general concepts are studied, i.e., definitions of celestial bodies, movements of planets, order in the solar system, perimeter, radius and diameter, among others. The implementation consists of several tests 
or challenges that follow a linear or sequential model (Nicholson, 2015; Sánchez Martín et al., 2020), in such a way that solving one of the tests provides a clue that allows the participant to move on to the next challenge, solving them in the established order until the last test is reached (Figure 1).

After briefly explaining what gamification and Escape Room are as an instructional tool in the first 10 minutes of the class, the participants begin the Escape Room. It consists of several challenges that participants must solve virtually during the class (Figure 2). The contextualization of the Escape Room is based on the astrophysicist Carl Sagan, who has left them a letter with a link to a digital lock that students must open to complete the virtual Escape room. To obtain the combination, the scientist proposes challenges with the objective of making participants scientifically literate about the Universe. The first challenge consists of reading the letter (1) that Carl Sagan has left for the participants on the university's Virtual Campus platform (Moodle). Here they find two links, the first leads to the digital lock (5) that they cannot open until they have completed all the tests. The second one leads them to the second challenge, a virtual puzzle (2) which, when solved, asks a question about the relative positions of the Sun, Earth and Moon when there is a lunar eclipse. Students must submit the solution to this question through the virtual campus and teachers correct in real time whether the answer is correct or incorrect. Students who "pass" can access the following challenge, which consists of a crossword on general contents about the Solar System (3). Some of the words in the crossword are marked and, by ordering them logically, they already know that they have to ask the teachers for a QR (Quick Response) code in order to download the next test. The fourth test consists of a table (4) with data about the planets in the Solar System (composition, order, satellites, and perimeter) that students must find out by looking in their notes, books or on the Internet. In the case of perimeter, they are given the diameters of each planet so that they can calculate it. Some of the words and numbers from the table are marked in such a way that if they are put in order, they form a mathematical operation in which a three-digit number is obtained. This combination is the one that must be entered in the digital lock (5) to reach the end and virtually leave the Escape Room.

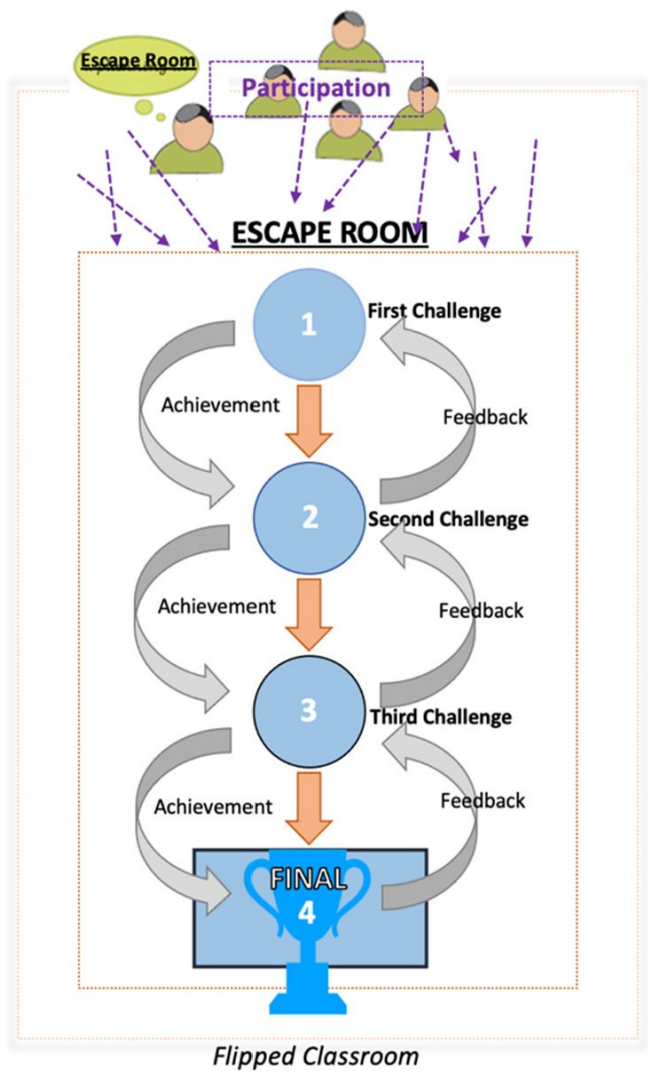

Figure 1. Sequencing of a linear Escape Room. Based on Nicholson's sequential model (2015) 


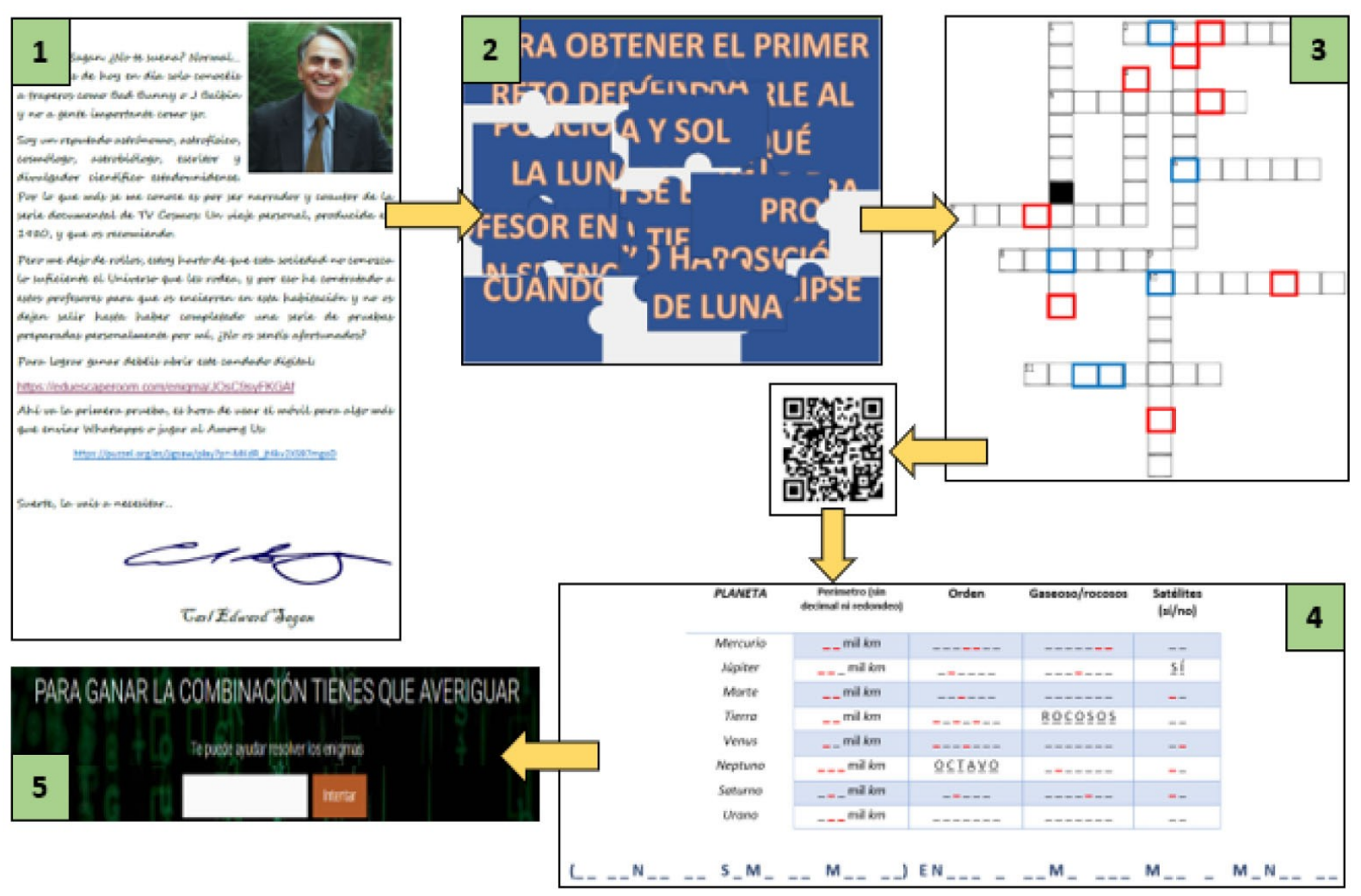

Figure 2. Challenges to be overcome by participants

\subsection{Data Analysis}

First, a descriptive analysis was performed, because of its common use as the most appropriate way to characterize, describe and draw conclusions from the data of a sample (Etxeberria \& Tejedor, 2005; Jeong, González-Gómez \& Cañada-Cañada, 2016). In order to measure the reliability of the questionnaire used in the study, a reliability analysis test was carried out by calculating the Ordinal Alpha (Zumbo, Gadermann \& Zeisser, 2007), since this is the most appropriate for measuring the reliability of instruments based on a Likert-type scale, obtaining a value of 0.91 in this case for the emotions questionnaire thus confirms that the questionnaire being used is adequate. The homogeneity of the sample was tested to reach plausible conclusions about the effects of the didactic tool evaluated. The Shapiro-Wilk normality test was performed to establish whether the data were normally distributed or not. Since the data were not normally distributed, non-parametric statistical tests were performed. Secondly, to establish the existence of significant differences between the values of the variables being studied before and after the intervention, the Mann-Whitney test was performed. Third, an effect size analysis was used to test the intensity of the effect that the proposed activity has on the variables studied. The SPSS Statistics 22.0 software was used in all cases.

\section{Results}

To measure the effects that the proposed implementation may have on the affective domain of the teacher trainees, the responses of the participants before and after the intervention (pre- and post- test) are analyzed. The responses have been statistically compared using non-parametric tests (Mann-Whitney U test), as shown in Table 2. 


\begin{tabular}{|c|c|c|c|c|c|}
\hline \multicolumn{6}{|c|}{ POSITIVE EMOTIONS } \\
\hline Emotion & Happiness & Satisfaction & Enthusiasm & Fun & Confidence \\
\hline Pre-test & 3.62 & 3.48 & 3.86 & 3.67 & 3.55 \\
\hline Post-test & 4.05 & 3.95 & 4.03 & 4.15 & 3.46 \\
\hline Sig* & $.047^{*}$ & $.015^{*}$ & .587 & $.034^{*}$ & .793 \\
\hline \multicolumn{6}{|c|}{ NEGATIVE EMOTIONS } \\
\hline Emotion & Nervousness & Frustration & Uncertainty & Worry & Boredom \\
\hline Pre-test & 2.57 & 1.5 & 2.83 & 1.83 & 1.48 \\
\hline Post-test & 3.51 & 3.23 & 3.33 & 2.51 & 1.64 \\
\hline Sig* & $.001 *$ & $.000 *$ & .066 & $.012 *$ & .937 \\
\hline
\end{tabular}

$*$ Differences are significant when the p-value $<0.05$.

Table 2. Comparison of the means (scale from 1 to 5) of the responses given by the participants for each emotion before and after the intervention

In general, an increase in all emotions, with the exception of confidence, was observed after the intervention. In particular, statistically significant differences were detected in 6 of the emotions analyzed in the study, 3 positive (joy, satisfaction and fun) and 3 negative (nervousness, frustration and worry). The differences were not significant for the positive emotions of enthusiasm and confidence, and for the negative emotions of uncertainty and boredom.

Figure 3 shows a bar graph of the comparison of means (scale from 1 to 5) of the 6 emotions in which significant differences were detected before and after implementing the Escape Room. Differences of $0.43,0.47,0.48,0.94,1.73$ and 0.67 points are observed in joy, satisfaction, fun, nervousness, frustration, and worry, respectively.

After analyzing and observing the differences in the affective domain of the students before and after implementing the virtual Escape Room proposed in this study, we want to know what effect this activity has on the statistically significant variables that were studied. For this purpose, a size effect analysis has been used. This analysis measures how strong the effect of a treatment is on the variables used and also provides a way to evaluate the data more comprehensively and accurately (Fritz, Morris \& Richler, 2012). To analyze the size effect, Cohen's "d" must first be calculated and, subsequently, we must see in which of the intervals defined by Cohen (1988) this value is found. Between 0.2-0.3, the effect of the intervention could be considered "small"; around 0.5-0.8 it can be considered to be a "medium" effect, and 0.9-1 to be a "large" effect. In this case, the following values were obtained when calculating Cohen's "d" for each significant variable: happiness (0.5), satisfaction (0.5), fun (0.5), nervousness (0.7), frustration (1) and worry (0.6). For all variables with significant differences, the effect of the activity is medium, except for the frustration variable where the effect is large.

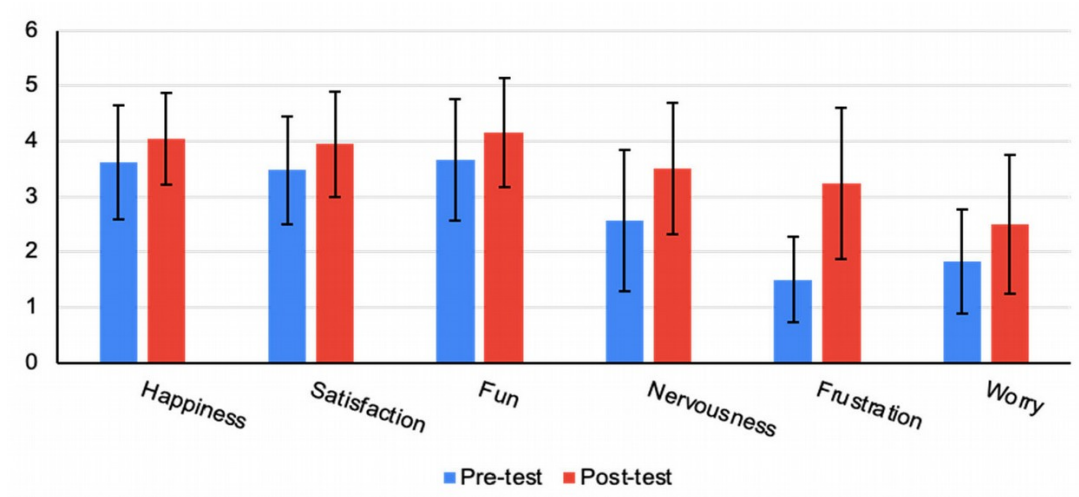

Figure 3. Emotions with significant differences in the comparison of means before and after the intervention 


\section{Discussion}

According to the results obtained after comparing the participants' responses before and after (pre- and post-test) implementing the virtual Escape Room proposed in the study, several significant differences have been detected regarding the affective domain of the participants.

With regard to positive emotions, the intensity with which the participants feel happiness, satisfaction and fun increased after completing the intervention (Figure 3). In this context, quite effective learning can be achieved during the virtual instruction, since it fosters positive emotional states, while applying an active instructional methodology (Aydogan, Bozkurt \& Coskun, 2015; Jeong et al., 2019a). Various authors (Vázquez \& Manassero, 2011; van Aalderen-Smeets \& van der Molen, 2015) indicate the importance of promoting positive emotions, especially in STEM disciplines, since the students begin to show disinterest in the sciences at an early age as the result of negative experiences. This negative image can carry over to adulthood and later diminish the selection of STEM careers. With regard to the analysis of the effect size, it is shown that the virtual Escape Room has a medium effect on the three significant positive emotions, i.e., happiness, satisfaction and fun. This type of effect is within the acceptable range in an analysis of the effect size (Navarro, García-Rubio \& Olivares, 2015) and corroborates that the activity performed has the effect of increasing these variables.

In relation to negative emotions, a significant increase in nervousness, frustration and worry is observed after implementing the virtual Escape Room (Figure 3). Even though virtual learning has many advantages, it also has various disadvantages, such as the difficulty of communication, coordination and monitoring, the capacity for student independence and the difficulty associated with the process, as compared to traditional learning, especially in practical scientific activities that require synchronous monitoring (Cowan, 1995; Arkorful \& Abaidoo, 2015), such as the one in this study. In this sense, difficulties were found with the live correction of tasks during the activity that was completed, due to the size of the sample as compared to the number of teachers. It is important to bear in mind the fact that most of the sample (nearly $70 \%$ ) comes from Humanities and Social Science programs. According to González-Gómez, Jeong, Gallego and Cañada-Cañada (2018), most of the students in Primary Education degree programs have studied this Baccalaureate mode, which is related to lower motivation and the presence of an unfavorable image and negative emotions towards science in general. Worth mentioning is the increase in frustration that the participants felt after completing the Escape Room. A significant increase greater than 1.5 points was observed for this item with regard to the pre-test. Furthermore, according to the effect size analysis, the implementation has a medium effect on the negative emotions of nervousness and worry, but a large effect on frustration. When it comes to doing an Escape Room activity, it is important to be aware that certain emotions like frustration and nervousness can appear, but this is normal, since these emotions are normal in this type of games, and without them, these activities would lose their fun component (Clauson et al., 2019). Frustration can occur for different reasons, such as the difficulty of a particular challenge, the time required to solve it or the lack of knowledge on the part of the participant. Here is where the role of the teacher is key in order to help and guide students on their journey to solve the most difficult tests (Nicholson, 2015; Sierra \& Fernández-Sánchez, 2019). In this sense, this function is extremely difficult in a remote teaching environment, and with the ratio that exists between teachers and the sample during this intervention. This is in agreement with the study by Jeong, González-Gómez, Gallego-Picó and Bravo (2019b), where it is observed that the feeling of isolation, excessive independence and self-governance, as well as the loss of motivation are the result of distance learning application and the lack of face-to-face interaction between teachers and students.

Over the course of the activity, several noteworthy aspects became apparent. The students solved each challenge individually, so that there were certain lags between the time each took to complete the challenges. Some tests required synchronous correction, and as there were 2 teachers for a total of 42 participants, there was quite a delay in some corrections, which could have a negative effect on the emotions of the participants. Generally speaking, the virtual Escape Room was completed within the expected time, which indicates that the difficulty of the tests was optimal, and they were neither too easy 
nor too difficult. There was also a feeling of pleasure generated among the participants after finishing the virtual Escape Room.

\section{Conclusions}

This research intends to study the effects that a virtual Escape Room has on the affective domain of the teacher trainee participants. According to the results analyzed, the implementation of a virtual Escape Room on the contents about the Universe increases the intensity of the positive emotions felt by the teacher trainees. Specifically, significant differences are detected in the emotions "happiness," "satisfaction" and "fun." An increase is also observed in negative emotions, especially in the emotions "nervousness," "frustration" and "worry," which is common, given that this type of intervention is correlated with a combination of positive and negative emotions. Difficulties have been found during the development of the Escape Room, because it was carried out in an online environment. These included the impossibility of interacting with several students on an individual basis at the same time and the difficulty of communication and monitoring of tasks on the part of teachers. This may have caused certain negative emotions, such as frustration, to increase to an excessive degree.

These are promising results for future research. Since it is a preliminary study with a small sample, the results cannot be extrapolated to teacher trainees in general. The implementation will be modified with the necessary improvements to ensure a suitable teaching-learning process, with the aim of improving the effects on the affective domain of teacher trainees. These improvements will include perfecting the experimental design, such as increasing the sample size and adding a control group in order to compare this instructional methodology to a traditional methodology, for example. Improvements can also be included in the instrument used, by adding open-ended opinion questions that inquire about the general satisfaction that the activity has produced, as well as which challenge the students have liked the best, and which they enjoyed the least.

\section{Declaration of Conflicting Interests}

The authors declare that they have no potential conflicts of interest with regard to the research, authorship and/or publication of this article.

\section{Funding}

The authors would like to express their appreciation to the Consejería de Economía, Ciencia y Agenda Digital of the Regional Government of Extremadura (Spain) and the FEDER Funds (Project IB18004 and Project GR18004) for the financing received in order to conduct this research.

\section{References}

Arkorful, V., \& Abaidoo, N. (2015). The role of e-learning, advantages and disadvantages of its adoption in higher education. International Journal of Instructional Technology and Distance Learning, 12(1), 29-42.

Aydogan, H., Bozkurt, F., \& Coskun, H. (2015). An assessment of brain electrical activities of students toward teacher's specific emotions. International Journal of Social, Behavioral, Educational, Economic, Business and Industrial Engineering, 9(6), 1977-2000.

Bisquerra, R. (2005). Emotional education and well-being. Barcelona: Praxis.

Borrego, C., Fernández, C., Blanes, I., \& Robles, S. (2017). Room escape at class: Escape games activities to facilitate the motivation and learning in computer science. JOTSE: Journal of Technology and Science Education, 7(2), 162-171. https://doi.org/10.3926/jotse.247

Brown, N., Darby, W., \& Coronel, H. (2019). An escape room as a simulation teaching strategy. Clinical Simulation in Nursing, 30, 1-6. https://doi.org/10.1016/j.ecns.2019.02.002 
Chick, R.C., Clifton, G.T., Peace, K.M., Propper, B.W., Hale, D.F., Alseidi, A.A. et al. (2020). Using technology to maintain the education of residents during the COVID-19 pandemic. Journal of Surgical Education, 77(4), 729-732. https://doi.org/10.1016/j.jsurg.2020.03.018

Clauson, A., Hahn, L., Frame, T., Hagan, A., Bynum, L.A., Thompson, M.E. et al. (2019). An innovative escape room activity to assess student readiness for advanced pharmacy practice experiences (APPEs). Currents in Pharmacy Teaching and Learning, 11(7), 723-728. https://doi.org/10.1016/j.cptl.2019.03.011

Cohen, J. (1988). Statistical power analysis for the behavioral sciences (2nd ed.). Hillsdale, NJ: Erlbaum.

Cowan, J. (1995). The advantages and disadvantages of distance education. In Howward, R., \& McGrath, I. (Eds.), Distance education for language teachers: A UK perspective (14-20). Multilingual Matters.

Deterding, S., Dixon, D., Khaled, R., \& Nacke, L. (2011). From game design elements to gamefulness: defining gamification. In Proceedings of the 15th International Academic MindTrek Conference: Envisioning Future Media Environments (9-15). https://doi.org/10.1145/2181037.2181040

Dunbar, R.L., Dingel, M.J., Dame, L.F., Winchip, J., \& Petzold, A.L. (2016). Student social self-efficacy, leadership status, and academic performance in collaborative learning environments. Studies in Higher Education, 38(9), 1507-1523. https://doi.org/10.1080/03075079.2016.1265496

Etxeberria, J., \& Tejedor, FJ. (2005). Descriptive data analysis in education. Madrid: La Muralla.

Ferrando, I., Hurtado, A., \& Beltrán, M.J. (2018). Formación STEM en el grado de maestro: Una experiencia docente. @ tic. Revista d'Innovació Educativa, 20, 35-42. https://doi.org/10.7203/attic.20.10946

Fritz, C.O., Morris, P.E., \& Richler, J.J. (2012). Effect size estimates: Current use, calculations, and interpretation. Journal of Experimental Psychology: General, 141(1), 2-18. https://doi.org/10.1037/a0024338

Gómez-Urquiza, J.L., Gómez-Salgado, J., Albendín-García, L., Correa-Rodríguez, M., González-Jiménez, E., \& Cañadas-De la Fuente, G.A. (2019). The impact on nursing students' opinions and motivation of using a "Nursing Escape Room" as a teaching game: A descriptive study. Nurse education today, 72, 73-76. https://doi.org/10.1016/j.nedt.2018.10.018

González, C.S. (2014). Estrategias para trabajar la creatividad en la Educación Superior: Pensamiento de diseño, aprendizaje basado en juegos y en proyectos. Revista de Educación a Distancia, 40, 1-15.

González-Gómez, D., Jeong, J.S., Cañada-Cañada, F., \& Gallego-Picó, A., (2017). La enseñanza de contenidos científicos a través de un modelo "Flipped": Propuesta de instrucción para estudiantes del Grado de Educación Primaria. Enseñanza de las Ciencias, 35(2), 71-87.

https://doi.org/10.5565/rev/ensciencias.2233

González-Gómez, D., Jeong, J.S., \& Cañada-Cañada, F. (2019). Enhancing science self-efficacy and attitudes of Pre-Service Teachers (PST) through a flipped classroom learning environment. Interactive Learning Environments, 1-12. https://doi.org/10.1080/10494820.2019.1696843

González-Gómez, D., Jeong, J.S., Gallego, A, \& Cañada-Cañada, F. (2018). Influencia de la metodología flipped en las emociones sentidas por estudiantes del Grado de Educación Primaria en clases de ciencias dependiendo del bachillerato cursado. Educación Química, 29(1), 77-88. https://doi.org/10.22201/fq.18708404e.2018.1.63698

Hill, J.R., Song, L., \& West, R.E. (2009). Social learning theory and web-based learning environments: A review of research and discussion of implications. American Journal of Distance Education, 23, 88-103. https://doi.org/10.1080/08923640902857713

Jeong, J.S., González-Gómez, D., \& Cañada-Cañada, F. (2016). Students' perceptions and emotions toward learning in a flipped general science classroom. Journal of Science Education and Technology, 25(5), 747-758. https://doi.org/10.1007/s10956-016-9630-8 
Jeong, J.S., González-Gómez, D., \& Cañada-Cañada, F. (2019a). How does a flipped classroom course affect the affective domain toward science course? Interactive Learning Environments, 1-13. https://doi.org/10.1080/10494820.2019.1636079

Jeong, J.S., González-Gómez, D., Gallego-Picó, A., \& Bravo, J.C. (2019b). Effects of active learning methodologies on the students' emotions, self-efficacy beliefs and learning outcomes in a science distance learning course. JOTSE: Journal of Technology and Science Education, 9(2), 217-227. https://doi.org/10.3926/jotse.530

Jeong, J.S., González-Gómez, D., \& Yllana-Prieto, F. (2020). Sustainable and flipped STEM education: Formative assessment online interface for observing pre-service teachers' performance and motivation. Education Sciences. Education Sciences, 10(10), 283. https://doi.org/10.3390/educsci10100283

Klisch, Y., Miller, L.M., Wang, S., \& Epstein, J. (2012). The impact of a science education game on students' learning and perception of inhalants as body pollutants. Journal of science education and technology, 21(2), 295-303. https://doi.org/10.1007/s10956-011-9319-y

McComas, W.F. (2014). STEM: Science, technology, engineering, and mathematics. In The language of science education (102-103). Rotterdam: SensePublishers. https://doi.org/10.1007/978-94-6209-497-0_92

Méndez, D. (2015). Estudio de las motivaciones de los estudiantes de secundaria de física y química y la influencia de las metodologías de enseñanza en su interés. Educación XXI, 18(2), 215-235. https://doi.org/10.5944/educxx1.14602

Miller, K., Sonnert, G., \& Sadler, P. (2018). The influence of students' participation in STEM competitions on their interest in STEM careers. International Journal of Science Education, 8(2), 95-114. https://doi.org/10.1080/21548455.2017.1397298

Mohamed, H., \& Lamina, M. (2018). Implementing flipped classroom that used an intelligent tutoring system into learning process. Computers \& Education, 124, 62-76. https://doi.org/10.1016/j.compedu.2018.05.011

Munir, M.T., Baroutian, S., Young, B.R., \& Carter, S. (2018). Flipped classroom with cooperative learning as a cornerstone. Education for Chemical Engineers, 23, 25-33. https://doi.org/10.1016/j.ece.2018.05.001

Navarro, J.J., García-Rubio, J., \& Olivares, P.R. (2015). The Relative Age Effect and its Influence on Academic Performance. PLOS ONE, 10(10), e0141895. https://doi.org/10.1371/journal.pone.0141895

Nicholson, S. (2015). Peeking behind the locked door: A survey of escape room facilities. White Paper. Available at: http://scottnicholson.com/pubs/erfacwhite.pdf

Nicholson, S. (2018). Creating engaging escape rooms for the classroom. Childhood Education, 94(1), 44-49. https://doi.org/10.1080/00094056.2018.1420363

Osborne, J., \& Dillon, J. (2008). Science education in Europe: Critical reflections. London: The Nuffield Foundation.

Pérez-Vázquez, E., Gilabert-Cerdá, A., \& Lledó-Carreres, A. (2019). Gamificación en la educación universitaria: El uso del escape room como estrategia de aprendizaje. In Investigación e innovación en la Enseñanza Superior: Nuevos contextos, nuevas ideas (660-668). Barcelona: Octaedro.

Prince, M. (2004). Does active learning work? A review of the research. Journal of Engineering Education, 93(3), 1-10. https://doi.org/10.1002/j.2168-9830.2004.tb00809.x

Sánchez-Martín, J., Corrales-Serrano, M., Luque-Sendra, A., \& Zamora-Polo, F. (2020). Exit for success. Gamifying science and technology for university students using escape-room. A preliminary approach. Heliyon, 6(7), 04340. https://doi.org/10.1016/j.heliyon.2020.e04340 
Sanders, M. (2009). STEM, STEM education, STEM mania. Technology Teacher, 68 (4), 20-26.

Sierra, M.C., \& Fernández-Sánchez, M.R. (2019). Gamificando el aula universitaria. Análisis de una experiencia de Escape Room en educación superior. REXE-Revista de Estudios y Experiencias en Educación, 18(36), 105-115. https://doi.org/10.21703/rexe.20191836sierra15

Su, C.H. (2019). The Effect of Users' Behavioral intention on gamification augmented reality in STEM (GAR-STEM) education. Journal of Baltic Science Education, 18(3), 450. https://doi.org/10.33225/jbse/19.18.450

Tai, R., Liu, C., Maltese, A., \& Fan, X. (2006). Planning early for careers in science. Science, 312(5777), 1143-1144. https://doi.org/10.1126/science. 1128690

Tobin, K. (2010). Reproducir y transformar la didáctica de las ciencias en un ambiente colaborativo. Enseñanza de las Ciencias, 28(3), 301-314. https://doi.org/10.5565/rev/ec/v28n3.3

Van Aalderen-Smeets, S.I., \& van der Molen, J.H.W. (2015). Improving primary teacher' attitudes toward science by attitude-focused professional development. Journal of Research in Science Teaching, 52(5), 710-734. https://doi.org/10.1002/tea.21218

Vázquez, A., \& Manassero, M.A. (2007). En defensa de las actitudes y emociones en la educación científica (I): Evidencias y argumentos generales (In defense of attitudes and emotions in science education (I): General arguments and evidence). Revista Eureka sobre Enseñanza y Divnlgación de las Ciencias, 4(2), 247-271. https://doi.org/10.25267/Rev_Eureka_ensen_divulg_cienc.2007.v4.i2.03

Vázquez, A., \& Manassero, M.A. (2011). El descenso de las actitudes hacia la ciencia de chicos y chicas en la educación obligatoria. Ciência \& Educação, 17(2), 249-268. https://doi.org/10.1590/S1516-73132011000200001

Vázquez, A., \& Manassero, M.A. (2017). Juegos para enseñar la naturaleza del conocimiento científico y tecnológico. Educar, 53(1), 149-170. https://doi.org/10.5565/rev/educar.839

Wiswall, M., Stiefel, L., Schwartz, A.E., \& Boccardo, J. (2014). Does attending a STEM high school improve student performance? Evidence from New York City. Economics of Education Review, 40, 93-105. https://doi.org/10.1016/j.econedurev.2014.01.005

Zumbo, B.D., Gadermann, A.M., \& Zeisser, C. (2007). Ordinal Versions of Coefficients Alpha and Theta For Likert Rating Scales. Journal of Modern Applied Statistical Methods, 6(1), 21-29.

https://doi.org/10.22237/jmasm/1177992180

Published by OmniaScience (www.omniascience.com)

Journal of Technology and Science Education, 2021 (www.jotse.org)

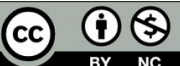

Article's contents are provided on an Attribution-Non Commercial 4.0 Creative commons International License. Readers are allowed to copy, distribute and communicate article's contents, provided the author's and JOTSE journal's names are included. It must not be used for commercial purposes. To see the complete licence contents, please visit https://creativecommons.org/licenses/by-nc/4.0/. 